\title{
Gender, Sexuality, Asylum and European Human Rights
}

\author{
Thomas Spijkerboer ${ }^{1}$ (D)
}

Published online: 16 December 2017

(C) The Author(s) 2017. This article is an open access publication

\begin{abstract}
Asylum law functions through a dichotomy between an idealized notion of Europe as a site characterized by human rights, and non-European countries as sites of oppression. In most social sciences and humanities literature, this dichotomy is seen as legitimizing European dominance and exclusion of non-Europeans. However, it is the same dichotomy which is used by asylum seekers to claim inclusion through the grant of asylum. Focusing on the inclusive potential of this exclusive dichotomy allows us to explore the ambiguities inherent in the dichotomy. In asylum claims based on persecution on account of gender and sexuality, it becomes evident that not all human rights are considered equally fundamental. In many cases, asylum seekers are required to renounce human rights in order to prevent persecution, for example by complying with patriarchal family norms. Even where this requirement is rejected, asylum law illustrates the ambiguous relation between Europe and human rights.
\end{abstract}

Keywords Gender · Human rights · Refugee law · Sexuality

\section{Introduction}

A well-established tradition of scholarship in the humanities and in social sciences maps the construction (both in these disciplines and in social reality) of a dichotomy between an idealized European self and a demonized, non-European other. In this construction, Europeans are characterized by enlightenment, progress, liberty, emancipation, and—particularly relevant for our context-human rights, while non-

Thomas Spijkerboer

t.p.spijkerboer@vu.nl

$1 \quad$ Vrije Universiteit Amsterdam, Amsterdam, The Netherlands 
Europeans are characterized by darkness, stagnation, oppression, subservience, and oppression. The dichotomy functions so as to legitimize European dominance and exclusion of non-Europeans. This line of analysis has been developed by scholars like Said (1991, 1993), Yuval-Davis (1997) and Hall (1988).

Writing in this tradition, Judith Butler has emphasized how the notion of sexual freedom has been appropriated by European state actors. They 'define Europe and the sphere of modernity as the privileged site where sexual radicalism can and does take place'. This is contrasted to assumedly pre-modern (usually Islamic) orthodoxy which is associated with foreign lands and with the people originating from them (Butler 2008, pp. 1-3). Butler notices a development to a situation where sexual freedom and religious freedom are seen as opposed, creating an antinomy within liberal discourse itself (ibid., p. 6). In a similar analysis, Bonnie Honig has pointed to the role of women as the 'good-girl markers of the French Enlightenment project's success' (Honig 2001, p. 65). Lesbian, gay, bisexual, and transgender (LGBT) rights have also become a powerful symbol of Europe, and function to distinguish the purportedly modern West from the East which is typecast as homophobic (Ayoub and Paternotte 2014, pp. 3, 12, 14). The terms sexual nationalism (Bilge 2012; Sreman and Ruard Ganzevoort 2015) and homonationalism (Puar 2007) have been used to specify the role of gender and sexuality in the construction of the dichotomy between Europe and the rest, and even within Europe between the advanced West and the East lagging behind (for an overview see Ayoub and Paternotte 2014, p. 16; Wekker 2016, pp. 113-117). In this process, 'Europe establishes itself as a space of sexual exceptionalism and ultimately as a sexual fortress under siege' (Colpani and Habed 2014, p. 74; comp. Moss 2014). This construction serves to legitimize various forms of European economic, political and military domination and exclusion.

In 2015 and 2016 Europe experienced a refugee crisis. However, the refugee population in Europe constitutes less than $0.5 \%$ of the total population, compared to between 3 and 5\% in Turkey, and an estimated 30\% in Lebanon. Therefore, the numbers in themselves cannot explain why the arrival of refugees in Europe was experienced as a crisis. Instead of arguing that the relatively small influx laid bare structural shortcomings of the European asylum system (Heijer et al. 2016; Thym 2016), I want to address another aspect that has contributed to the experience of a refugee crisis. The aspect I want to point out concerns the process in which asylum seekers and refugees destabilize the dichotomy justifying European domination and exclusion, outlined above. They exploit the ambiguities which are inherent in the dichotomy in a double move. As non-Europeans, they invoke human rightswhereas the dichotomy constructs non-Europeans in opposition to these values. And at the same time, they make the dichotomy function so as to justify their inclusion (through the grant of asylum) instead of their exclusion. In the following, I will map this process, and subsequently I will analyse how European asylum law discourse deals with this disruption of the dichotomy.

In the following, I want to expand the analysis of sexual nationalism and homonationalism so as to include this rarely noticed process, in which people who have been constructed as outsiders seek to invoke the idealized European identity so as to delegitimize their exclusion. In other words, they try to undo their exclusion 
through the very discursive processes which justify their exclusion. This process occurs in asylum cases, and will be analyzed by focusing on asylum claims that are based on gender and sexuality (and in a few cases on minoritarian religious convictions). In the context of contemporary asylum law, such claims are formulated in terms of human rights (e.g. Anker 2002; Millbank 2009). In the asylum context, people who are marked as non-European cross the demarcation line between Europeans and non-Europeans by embracing the idealized European selfimage and asking for protection against non-Europeans. This creates a dilemma for the European idealized self-image. If it takes itself seriously, the asylum claims of these people cannot be accepted because they are considered unenlightened nonEuropeans and hence should be excluded because they threaten to undermine the normative order. But simultaneously, the asylum claims cannot be rejected because that would require denying how unenlightened non-European societies are when dealing with, especially, women or LGBT people. In asylum cases where gender and sexuality have been successfully made to be at the heart of the matter, both the idealized European self-image and the excluding effect of the dominant normative order risk being destabilized. In this manner, I want to expand the existing analyses on sexual nationalism and homonationalism, which have put most emphasis on the first two elements (European identity building and exclusion). Inspired by the work of Sarah van Walsum, I will highlight the creative ways in which groups with very limited power (migrant women and migrant sexual minorities) have exploited ambiguities in the dominant normative order.

\section{Asylum: The Other Appeals To Us}

In asylum law European state authorities are confronted with Othered subjects who appeal to the human rights norms which are constructed as characteristic for Europe and the lack of which is characteristic for non-Europeans. This is a strategic process in which asylum applicants tend to depict their country of origin in accordance with European stereotypes: as a place of cruelty, violence, and human rights violations. It makes sense for them to represent the situation in their country of origin as so bad that the only way to protect their fundamental human rights is to enable them not to return by granting asylum. In this sense, they reinforce the European/non-European dichotomy (Comp. Macklin 1995; Crawley 1997; Spijkerboer 2000). Their argument is: if our human rights are to be respected, we have to be allowed to remain in Europe.

But simultaneously, these asylum applications undermine the dichotomy. People who are marked as Other (asylum seekers from non-European countries) do not conform to the vilified image which European states have available for nonEuropeans. Quite the contrary: these asylum seekers appeal to the European value system because, instead of lacking it, they actually share it. They ask European states to protect them against the vilified outsiders not by excluding, but by including them through the grant of asylum. In this way, they threaten to undermine the dichotomy between the idealized image of Europeans and the vilified image of non-Europeans. If, for example, Muslim women escaping human rights violations 
are granted asylum, they are recognized as having values very similar to ours (such as an abhorrence of cruelty, violence and discrimination). This destabilizes the notion that Muslims are unenlightened barbarians; these women are like us. But if, to the contrary, they are denied asylum, European states deny that values such as women's rights and non-discrimination are universal and characteristic for Europe. If people are deported back to a situation where their fundamental rights are at risk, this undermines the notion that Europe is a beacon of human rights.

In this way, asylum applications simultaneously confirm and undermine the vilification of non-Europeans, just like they confirm and undermine the glorification of Europe. In this article this instability, as well as the ways in which asylum seekers have sought to exploit it, will be analyzed by focusing on a piece of legal doctrine which is applied in asylum cases of, in particular, women and LGBT people. Over the past decades, they have been expected to limit the risks they run upon return to the country of origin by what the European Court of Human Rights (ECHR) has called 'playing the game', ${ }^{1}$ and what is referred to as discretion reasoning in literature. ${ }^{2}$ The central idea in 'playing the game' reasoning is that particular behaviour (such as giving expression to one's religious conviction or sexual or gender identity) may trigger oppressive responses in the country of origin. Asylum authorities have argued that in such cases, the asylum seeker can be reasonably expected to adapt his or her behaviour in such a manner that these oppressive responses are not triggered. On this issue, two diverging lines occur in European legal practice.

\section{'Playing The Game' Required}

In a number of judgments of the European Court of Human Rights, the requirement to 'play the game' is applied quite openly. In order to illustrate the variety of cases in which this occurs, I will deal with one case on Pakistani Christians; one case on women from Yemen; and one case on a Libyan homosexual.

In Z. and T. $v$ United Kingdom (2006), the European Court of Human Rights declared an application manifestly unfounded where two Pakistani nationals were found to be 'unable, due to the prevailing situation in a largely Islamic country, to live as Christians without risking adverse, if not worse, attention or taking steps to conceal their religion'. It explained the rejection of their claim by stating that

(o)n a purely pragmatic basis, it cannot be required that an expelling Contracting State only return an alien to a country where the conditions are in full and effective accord with each of the safeguards of the rights and freedoms set out in the Convention.

\footnotetext{
1 This term is used, with quotation marks, in ECHR [2011] Sufi and Elmi v United Kingdom, 8319/07 and 11449/07, para. 275.

2 On discretion reasoning see Millbank (2009), Hathaway and Pobjoy (2012), Wessels (2013, 2016), Battjes (2013), Spijkerboer (2013, pp. 219-222). The more generic concept of 'playing the game' is used here, because the discretion does not cover the cases of women, who are not required to be 'discreet' about their gender but to comply with stereotypical notions of appropriate behaviour.
} 
The Court explains that the freedom of religion is one of the foundations of a democratic society and that manifesting one's religion is an essential part of that freedom:

This is however first and foremost the standard applied within the Contracting States, which are committed to democratic ideals, the rule of law and human rights. (...) Otherwise it would be imposing an obligation on Contracting States effectively to act as indirect guarantors of freedom of worship for the rest of the world.

The Court then goes on to state that only if the situation of the applicant leads to a real risk of torture or inhuman or degrading treatment, removal to the country of origin would constitute a violation of the European Convention on Human Rights. ${ }^{3}$ The Court here makes a double move. First, it basically argues that only the prohibition of torture and inhuman or degrading treatment is really universal. All other human rights do not need to be guaranteed by European states through nonremoval to third states (such as Pakistan) where these rights are violated. It thus distinguishes one universal human right (being the right not to be subjected to torture or inhuman or degrading treatment) and other human rights which are a matter of local practice and which can be protected or not 'on a purely pragmatic basis'. In itself, this notion is part and parcel of refugee law. The idea that not all violations of human rights, but only some of them should lead to asylum is widely accepted. ${ }^{4}$ This broad doctrinal support does not, however, diminish the significance of the Court stating here that-torture and inhuman or degrading treatment aparthuman rights first and foremost apply within the Contracting states of the Council of Europe. Secondly, it implicitly assumes that the two applicants will, as a matter of fact, conceal their religion and will not live openly as Christians. If the Court were to have assumed they would live openly as Christians, it would have been forced to conclude that they would 'risk adverse, if not worse attention', in which case removal would have been a violation of the right not to be subjected to torture or inhuman or degrading treatment. So the Court both distinguishes between one truly universal human right, and other more local human rights; and it incorporates discretion reasoning into its assessment of how the individuals concerned would behave if they were deported to Pakistan.

A. A. and others $v$ Sweden (2012) concerns six Yemenite nationals: a mother, her three daughters and two sons. At the moment of the judgment, only the youngest daughter is still a minor. The mother and the oldest daughter both have been forced to marry at a young age. Arrangements had already been made to forcibly marry the second daughter at the time she and her mother fled the country, while the youngest

\footnotetext{
3 True: the Court adds that a flagrant violation of other Convention rights may lead to a prohibition of removal too, but adds that it is hard to imagine a case where this would not also involve torture or inhuman or degrading treatment. The Court has later identified one such case, concerning the right to fair trial: ECHR [2012] Othman v United Kingdom, 8139/09.

4 Grahl-Madsen (1966, pp. 193-216), Goodwin-Gill and McAdams (2007, pp. 90-92), Hathaway and Foster (2014, pp. 193-208). European law defines persecution as 'a severe violation of basic human rights', Article 9(1)(a) Directive 2011/95, thus evoking the idea that human rights violations may be not severe and that there are human rights which are not basic.
} 
daughter would probably be married forcibly as well. The mother's husband was very strict with her, burnt her and threatened her with a knife. She had tried to obtain a divorce but had been told by the Court to solve her private problems with her husband. The husband of the oldest daughter treated her like a servant but had agreed to divorce her if he were to be reimbursed the USD 4000 dowry. The mother had petitioned to prevent the marriage of the second daughter but the Court decided that the head of the family was to make this decision. The mother's brother has helped to get the mother and second daughter out of the country, later followed by the other children.

The Court concludes that the forced return of the mother and her five children would not violate Article 3 ECHR. Although the Court's reasoning is detailed, the recurring main argumentation focuses on the availability of protection for the women in the country of origin, Yemen.

The claim of the applicants essentially is that the women are forced to marry without their consent, are defenceless against violence from their husbands, and run the risk of crimes of honour if they try to leave their husbands. Together with the corroborating country information, this could have been considered as evidence that the women have been or will be married without their consent, which has already or will in all likelihood imply sexual intercourse without their consent. But while the risk of forced marriage had materialised for three of the four female claimants before they left the country of origin, this is considered as insufficient (even in these three cases) even for concluding that the applicants have passed the initial threshold ('adduce evidence capable of proving deportation would run contrary to Article 3', which would allow the respondent state to dispel any doubt about the risk).

The Court finds the applicants quite capable of taking care of themselves. The first applicant is praised for having 'shown proof of independence by going to court in Yemen on several occasions to file for divorce from $\mathrm{X}$ and also shown strength by managing to obtain the necessary practical and financial means to leave Yemen' (ibid., para 83). The two sons are 'now adult men, they are free to find jobs and settle where they wish within the country' (ibid., para 80). The oldest daughter 'would be able to obtain a divorce if she paid the money demanded' (ibid., para 89). Of the second daughter the court finds it relevant to remark that 'she is now adult' (ibid., para 92).

Implicitly, the Court uses a very wide notion of agents of protection. The two by now adult sons of A.A., as well as her brother, are mentioned as sources of protection. The brother 'has continued to assist the applicants', and they

have not shown that (they) cannot count on his protection in Yemen. Moreover, if returned, the first applicant would be accompanied by her two adult sons who could also support her and which would enable her to live away from her husband. (ibid., para 83).

The Court's analysis on this point is devoid of any form of normativity. Are the brother and sons under any kind of obligation to protect the women; are the women in any way entitled to protection by the men? Are there any guarantees that the men will deliver? Will they expect something in return for their services and for the risks they run in doing so? The Court simply finds it plausible that A.A.'s brother will 
protect her because he has assisted her before. And it assumes that the sons will be a source of protection, without indicating why.

In the Court's reasoning, forced marriage (with the domestic and sexual violence that comes with it) is in effect considered as insufficiently serious. This means that patriarchal notions of women belonging to men are being reinforced by the judgment. The Court takes as given, and thereby reproduces the assumption that seems to be dominant in Yemenite family relations that women need a male relative (father, husband, brother, or son) in order to be protected against violence of other men. The judgment assumes and thereby reproduces the social system of female dependency on male relatives, of which forced marriage forms a part. Article 3 ECHR apparently does not protect women against patriarchy even in its most violent form. It requires women to play by its rules - try to pay back the dowry, try to identify nicer men to protect you and hope that alternative dependency will not turn violent as well.

This judgment is part of a substantial number of judgments in which women are expected to adapt to, and simply get used to living with patriarchal violence by being brave or invoking the protection of male relatives. ${ }^{5}$

The third case, M.E. $v$ Sweden (2014), concerns a Libyan homosexual. ${ }^{6}$ The central question was whether he could be removed to Libya in order to await the outcome of a pending procedure on family reunion there. The Court mentions that during a Skype conversation with the applicant's family in Libya his husband presented himself as a woman. 'In the Court's opinion, this indicates that the applicant has made an active choice to live discreetly and not reveal his sexual orientation to his family in Libya' (ibid., 2014, para. 86). It then concludes that the family reunion procedure could be reduced to approximately four months:

this must be considered a reasonably short period of time and, even if the applicant would have to be discreet about his private life during this time, it would not require him to conceal or suppress an important part of his identity permanently or for any longer period of time. Thus, it cannot by itself be sufficient to reach the threshold of Article 3 of the Convention. (ibid., para. 88).

This judgment is in line with other cases where the Court expected gay men to ward off a risk of inhuman treatment by living discreetly. ${ }^{7}$

In two judgments the European Court of Human Rights applied the same idea (people can be expected to 'play the game'), but concluded that in the particular circumstances of the case, the asylum seekers were unable to do so and therefore concluded that their removal would be a violation of Article 3 ECHR. In a case

\footnotetext{
5 Compare ECHR [2007] Collins and Akaziebie v Sweden, 23944/05 (Female Genital Mutilation or FGM, Nigeria); ECHR [2011] Izevbekhai and others v Ireland, 43408/08 (FGM, Nigeria); ECHR [2011] Ameh and others $v$ United Kingdom, 4539/11 (FGM, Nigeria); ECHR [2011] Omoredo v Austria, 8969/10 (FGM, Nigeria); ECHR [2012] R.W. and others v Sweden, 35745/11 (FGM, Kenya); ECHR [2014] S.B. v Finland 17200/11, (domestic violence, Morocco); ECHR [2015], R.H. v Sweden 4601/14, (single woman, Mogadishu); ECHR [2016] Sow v Belgium, 27081/13 (FGM, Guinée). See extensively Lage (2016).

6 ECHR [2014] M.E. $v$ Sweden, 71398/12. The case was referred to the Grand Chamber but subsequently struck out because Sweden decided not to deport M.E.
}

7 ECHR [2004] F. v United Kingdom, 17341/03; ECHR [2004] I.I.N. v the Netherlands, 2035/04. 
concerning return to areas of Somalia dominated by Al Shabaab, 'the Court considers it unlikely that a Somali with no recent experience of living in Somalia would be adequately equipped to "play the game" and this is even harder "for Somalis who have been out of the country long enough to become "westernized" as certain attributes, such as a foreign accent, would be impossible to disguise'. ${ }^{8}$ The Court here does not reject the requirement itself, but merely concludes on factual grounds that 'playing the game' will not be possible for people who have been absent from the area for a while. In a case about a divorced Afghan woman, the Court concluded that she simply was unable to access 'male support and protection', and therefore found her removal in violation of Article 3 ECHR.'

In these cases, we can observe one way of dealing with the destabilization caused by asylum claims of non-European women and LGBT asylum seekers. In this mode, asylum law reasoning maintains its exclusionary potential (the claims are dismissed, the claimants can be removed to their countries of origin) by qualifying the universal nature of human rights. The right to freely express religious or sexual identity, and the right to choose one's own spouse are not qualified in respect to the internal European legal order, but they are considered to be not so fundamental that violation thereof can give rise to a right not to be removed. This distinction is a core element of asylum law. But it creates a dissonance in human rights law, because it brings to light that some fundamental rights are, actually, not fundamental because facilitating their violation by removal is not in violation of these rights.

\section{'Playing The Game' Rejected}

However, this is not the only way to deal with the destabilization. Other courts have sought to uphold the idea that all fundamental rights are fundamental; at the same time, as we will see, they have not altogether given up the exclusionary potential of asylum law.

To begin with: in three cases, judges of the European Court of Human Rights submitted dissenting opinions. In A.A. and others $v$ Sweden (2012), judge PowerForde argues that the domestic violence of which the women have been victim constitutes inhuman treatment in the meaning of Article 3. The Swedish asylum authorities have argued that the women could get away from their husbands by paying back the dowry, and have referred to their predicament as 'problems within "the personal sphere caused, inter alia, by the country's traditions"'. Power-Forde disagrees:

The applicants' problems 'within the personal sphere' that are caused by their 'country's traditions' are, to my mind, sufficiently serious as to amount to a violation of Article 3. To demand that vulnerable women exhaust meagre, discriminatory and ineffective 'remedies' before courts that can sanction the

\footnotetext{
${ }^{8}$ ECHR [2011] Sufi and Elmi v United Kingdom, 8319/07 and 11449/07, para 275.

9 ECHR [2010] N. v Sweden, 23505/09.
} 
marriage of a 12 year child (as did the Yemeni court in this case) - before a grant of international protection may be considered-is to demand too much.

Power-Forde also disagrees with the majority ruling in M.E. $v$ Sweden (2014). 'The fact that the applicant could avoid the risk of persecution in Libya by exercising greater restraint and reserve than a heterosexual in expressing his sexual orientation is not a factor that ought to be taken into account'. She refers to developments in international doctrine and case law, and addresses the relatively short period during which M.E. would have an exercise restraint as follows:

This Court has held that to deprive a person of his reading glasses for a few months reaches the required threshold under Article 3. (...) Depriving this applicant of his dignity for a similar or longer period by expecting him to hide an intrinsic part of his identity for fear of persecution does not. (...) Such a requirement of forced reserve and restraint in order to conceal who one is, is corrosive of personal integrity and human dignity.

In a Somalian case, R.H. v Sweden (2015), where a single woman was held to have access to family support and a male protection network, judges Zupančič and De Gaetano object to returning a single woman

to an essentially dysfunctional society, but also to one that is positively hostile to her status and to what she has done these last ten years plus. Whatever family the applicant may still have in Mogadishu, especially male members, they will be equally, if not more, hostile.

In these dissents, Power-Forde, Zupančič and De Gaetano object to the very notion that women and gays have to accept a situation which is discriminatory and violent and simply should try to fit in. Whereas the majority of the Court denies the universal character of human rights (in Z. and T. $v$ United Kingdom even explicitly so), the dissenters emphasize the shared human dignity of the applicants and Europeans by insisting on equal protection of their fundamental rights. The majority and the dissenters both deal with the instability surrounding asylum applications of women and LGBT, be it in different ways.

In the case law of the Court of Justice of the EU, the expectation that people 'play the game' has been rejected altogether. Whereas the European Court of Human Rights has dealt with asylum cases mainly under Article 3 ECHR, the Court of Justice of the EU has addressed discretion reasoning in the context of the refugee definition. There are two main differences of substance between these legal contexts. Firstly, Article 3 ECHR blocks removal if there is a real risk of torture or inhuman or degrading treatment in the country of origin, whereas the refugee definition foresees protection for people with a well-founded fear of being persecuted in the country of origin. These different wordings may be relevant in other contexts, but do not play a role in our context. Secondly, the refugee definition requires that the likelihood of persecution is related to one of the five persecution grounds (race, religion, nationality, membership of a particular social group, or political opinion) whereas for the evaluation of an asylum claim under Article 3 ECHR it is irrelevant why a person runs a risk. Battjes has argued that this makes 
discretion reasoning more plausible under Article 3 (Battjes 2013). As we saw, discretion reasoning may be rejected in the ECHR context as well, as evidenced by the dissenting opinions referred to above. On the other hand, we will see that discretion reasoning is quite resilient in the refugee definition context too. Therefore, I will not focus on the different legal contexts (European Convention of Human Rights versus Refugee Convention) of the cases.

In a case concerning possible persecution on the ground of religion, the EU Court of Justice echoed the Z. and T. $v$ United Kingdom judgment by ruling that not 'any interference with the right to religious freedom guaranteed by Article 10(1) of the Charter constitutes an act of persecution requiring the competent authorities to grant refugee status'. ${ }^{10}$ Thus, the Court of Justice like the European Court of Human Rights is of the opinion that European states can return people to their country of origin even if they run a foreseeable risk of human rights violations there, provided that the violation is not 'severe' and therefore does not have 'a significant effect on the person concerned'. ${ }^{11}$ But whereas the European Court of Human Rights implicitly relied on discretion reasoning in Z. and T. $v$ United Kingdom, the EU Court of Justice held that none of the rules of European law state

that, in assessing the extent of the risk of actual acts of persecution in a particular situation, it is necessary to take account of the possibility open to the applicant of avoiding the risk of persecution by abstaining from the religious practice in question and, consequently, renouncing the protection which the Directive is intended to afford the applicant by conferring refugee status. ${ }^{12}$

The Court of Justice rephrases the notion that an asylum applicant is expected to refrain from religious expressions as 'renouncing the protection' refugee law 'is intended to afford'. In conformity with this, it rules that what states have to determine is whether 'upon his return to his country of origin, the person concerned will follow a religious practice which will expose him to a real risk of persecution'. It adds: 'The fact that he could avoid that risk by abstaining from certain religious practices is, in principle, irrelevant'. The case concerned Pakistani Ahmadiyya-an Islamic reformist movement which may lead to prosecution if Ahmadiyyas describe their faith as Islam, preach or propagate their faith or invite others to accept it. ${ }^{13}$

Campaigns holding that lesbian, gay, bisexual and transgender asylum applicants should not be 'sent back to the closet' have been waged in many Western countries (see extensively Jansen and Spijkerboer 2011, pp. 33-40; Wessels 2013). The EU Court of Justice in 2013 held that it is determinative whether 'on return to his country of origin his homosexuality would expose him to a genuine risk of persecution', and added: 'The fact that he could avoid the risk by exercising greater restraint than a heterosexual in expressing his sexual orientation is not to be taken into account in that respect.' It expressly held that 'the competent authorities cannot reasonably expect, in order to avoid the risk of persecution, the applicant for asylum

\footnotetext{
${ }^{10}$ Court of Justice of the European Union 12 September 2012, C-71/11 and C-99/11, para. 79.

${ }^{11}$ Ibid. para. 59.

12 Ibid. para. 78.

13 Ibid, para 31.
} 
to conceal his homosexuality in his country of origin or to exercise reserve in the expression of his sexual orientation'. ${ }^{14}$

At first sight, these judgments seem to rule out the possibility that refugee status is denied because the individuals are able to 'play the game' and thus evade persecution. The Court of Justice seems to rule that religious people are free to publicly exercise their religion and that sexual minorities can live openly and freely, ${ }^{15}$ even if their choice to do so may expose them to persecution. Does this mean that the EU Court of Justice has escaped or even solved the dilemma posed by the instability surrounding the asylum applications of women and LGBT people?

Janna Wessels has pointed out that the national courts which had referred the cases to the EU Court of Justice interpreted the Court's judgments in such a manner that the difference with discretion reasoning is minimal, thus undermining the Court of Justice's 'abolition' of discretion reasoning (Wessels 2016). In the judgments in which they applied the preliminary rulings they had asked for, the German Bundesverwaltungsgericht (Federal Administrative Court) ${ }^{16}$ as well as the Dutch Raad van State (Council of State) ${ }^{17}$ emphasized the factual aspect of the criterion formulated by the EU Court of Justice. The Court of Justice stated that it is determinative whether the applicant, upon return to the country of origin, will be exposed to a genuine risk of persecution. The domestic courts seize upon this aspect of the judgments. If it is not plausible that the applicant will engage in activities disclosing minoritarian religious or sexual preferences, but will act in such a manner that he or she will not run a risk of persecution, there is no reason to grant refugee status. The Raad van State does this by focusing on past behaviour to establish whether it is plausible that, upon return, the applicant will behave in such a manner that there is a likelihood of persecution. The Bundesverwaltungsgricht does this by looking at the intensity of the applicant's religious beliefs, the point of which is to establish whether the applicant is in fact likely to engage in risky behaviour. Both national courts accept that applicants cannot, as a normative matter, be required to conceal their religion or sexual orientation; this is not to be expected. But they insist on whether, as a factual matter, applicants are likely to conceal their religion or sexual orientation; it is still decisive whether this can be expected. Both courts have made inconclusive statements on the situation where it is plausible that applicants will conceal their religion or sexual orientation out of fear of persecution (as

\footnotetext{
14 Court of Justice of the European Union 7 November 2013, C-199/12 to 201/12, para. 75-76.

15 This terminology was adopted in HJ (Iran) and HT (Cameroon) v Secretary of State for the Home Department [2010] UKSC 31. Wessels (2013) gives an analysis of the UK Supreme Court's ruling that is similar to the one given here of the Court of Justice's judgments.

16 Bundesverwaltungsgericht 20 February 2013, BVerwG 10 C20.12, ECLI:DE:BVerwG:2013: 200213U10C20.12.0, English translation as provided by the Bundesverwaltungsgericht itself available on RefWorld at http://www.refworld.org/cgi-bin/texis/vtx/rwmain?page=search\&docid=518a90024\& skip=0\&category=LEGAL\&publisher=DEU_BUNDESVERWALT\&advsearch=y\&process=y\&allwords= \&exactphrase $=\&$ atleastone $=\&$ without $=\&$ title $=\&$ monthfrom $=02 \&$ yearfrom $=2013 \&$ monthto $=02 \&$ yearto $=$ $2013 \&$ coa $=\&$ language $=\&$ citation $=$.

17 Afdeling bestuursrechtspraak van de Raad van State 18 December 2013, case 201012342/1/V2, ECLI:NL:RVS:2013:2423 translation of relevant passages at http://www.refworld.org/publisher,NTL_ COS,,,53ba91824,0.html.
} 
opposed to out of a 'natural' reticence in order to 'avoid harming his relationships with his family, friends and colleagues'). ${ }^{18}$

Thus, far from having 'solved' the dilemma posed by the asylum applications of women and LGBT people, the EU Court of Justice's case law shows that the seemingly more rights-oriented approach advocated by Power-Forde, Zupančič and De Gaetano may be construed in a way that is as duplicitous as the position of the European Court of Human Rights. The EU Court of Justice suggests how, in response to the destabilization resulting from these asylum claims, the universal nature of fundamental rights can remain uncompromised, while simultaneously maintaining the exclusionary potential of asylum law.

\section{Human Rights: Universal or Excluding?}

Nevertheless, the difference between these two sets of case law matters. In the Strasbourg line of thinking, asylum can be denied because people are expected to give up fundamental rights in order to protect themselves against harm, instead of being granted asylum in Europe in order to be protected from harm. In the Luxembourg line of thinking, the idea that people have to give up the rights which refugee law was designed to protect is counter-intuitive. The difference is relevant on at least two points. First, public discourse is affected. The shift from 'we cannot guarantee all human rights of everyone everywhere' to 'LGBT people should not be sent back to the closet' marks a shift towards a more universalist notion of human rights, and away from a local and culturalized notion of human rights. Secondly, it has simply become harder to dismiss asylum applications of persecuted women and religious and sexual minorities. The fact that one ground for dismissing asylum applications has been delegitimized makes a difference in actual practice.

But in addition to this, neither position succeeds in doing away with the instability underlying European asylum law. In both lines of case law, two positions are taken simultaneously while there is considerable tension between them. On the one hand, as a practical matter Europe can only grant asylum to people facing really bad human rights violations; people facing 'minor' violations will have to get by on their own. On the other hand, Europe positions itself as the region with the most advanced human rights protection in the world, which logically includes protection against 'minor' human rights violations (and possibly considers the notion of minor human rights violations as a contradiction in terms). Whereas the tension between these positions may go unnoticed as long as it remains abstract, it becomes very visible as soon as concrete situations are taken into account. In these asylum cases, the dichotomy which Butler and others have identified threatens to be destabilized. If human rights are to be truly universal, they result in forcing European states to grant asylum to (and thereby to include) Muslim and other non-European persons. And if Muslims are to be excluded, this requires representing human rights as local preferences with only limited universal validity.

\footnotetext{
${ }_{18}$ Terminology taken from HJ (Iran) and HT (Cameroon) $v$ State Secretary for the Home Department [2010] UKSC 31, para. 22 and 61.
} 
The tension between these two positions has been acknowledged explicitly on the point of criminalization of homosexuality. When assessing whether the existence of criminal sanctions against same-sex sexual acts in Ireland by itself (regardless of enforcement) constitutes a violation of human rights, in the European context the European Court of Human Rights held that

the maintenance in force of the impugned legislation constitutes a continuing interference with the applicant's right to respect for his private life (...) In the personal circumstances of the applicant, the very existence of this legislation continuously and directly affects his private life (...) either he respects the law and refrains from engaging - even in private with consenting male partners in prohibited sexual acts to which he is disposed by reason of his homosexual tendencies, or he commits such acts and thereby becomes liable to criminal prosecution. $^{19}$

It approvingly quoted an expert who had stated:

One of the effects of criminal sanctions against homosexual acts is to reinforce the misapprehension and general prejudice of the public and increase the anxiety and guilt feelings of homosexuals leading, on occasions, to depression and the serious consequences which can follow from that unfortunate disease. $^{20}$

So the Strasbourg court found the mere existence of legislation criminalizing samesex sexual conduct a continuing and direct violation of human rights, resulting in anxiety, guilt feelings and on occasion in depression. The Court of Justice of the EU was asked to decide whether the criminalization of same-sex sexual acts by itself constituted persecution in the sense of the refugee definition which, in a European directive intended to harmonize the notion of refugee, mentioned as one example of persecution 'legal, administrative, police and/or judicial measures which are in themselves discriminatory or which are implemented in a discriminatory manner' ${ }^{21}$ Although criminalization of same-sex sexual acts obviously is a 'legal measure which in itself is discriminatory' and thus fulfils the criterion, the Court of Justice held that 'the mere existence of legislation criminalising homosexual acts cannot be regarded as an act affecting the applicant in a manner so significant that it reaches the level of seriousness necessary for a finding that it constitutes persecution. ${ }^{22}$ Additionally, according to standard case law of the European Court of Human Rights, treatment can be degrading when it may arouse 'feelings of fear, anguish and inferiority capable of humiliating and debasing them'. ${ }^{23}$ Why a permanent infringement on the right to respect for private life which results in 'anxiety and

\footnotetext{
${ }^{19}$ ECHR [1988] Norris $v$ Ireland, 10581/83, para. 38, quoting ECHR [1981] Dudgeon v United Kingdom, 7525/76, para. 41.

20 Ibid, para. 33.

21 Article 9(2)(b) Directive 2011/95.

22 Court of Justice of the European Union 7 November 2013, Cases C-199/12 to C-201/12, para. 55.

23 ECHR [1989] Soering v Germany, 14038/88, para 100; ECHR [2005] Bader and Kanbor $v$ Sweden, 13284/04, para. 43-49; ECHR [2006] D. et autres c. Turquie, 24245/03, para. 55-58.
} 
guilt feelings of homosexuals leading, occasionally, to depression, ${ }^{24}$ would not qualify as degrading treatment remains unclear. In his separate opinion in M.E. $v$ Sweden, judge De Gaetano pointed to this inconsistency, and wrote that the Court of Justice's position 'could be seen as somehow undermining the standards set by the Court as far back as the 1980s in connection with the criminalization of homosexual acts and the resulting violation of Article 8, ${ }^{25}$

Another issue where the tension between human rights law for internal use and in the asylum context has come to light is in the assessment of a person's sexual or gender identity. The European Court of Human Rights has consistently held that gender identification, sexual orientation and sexual life fall within the personal sphere protected by the right to private life. ${ }^{26}$ The case of Van Kück v Germany (2009) 'touched upon the applicant's freedom to define herself as a female person, one of the most basic essentials of self-determination' ${ }^{27}$ In a dispute about whether her gender reassignment was covered by Van Kück's health insurance, a German court had

on the basis of general assumptions as to male and female behaviour, substituted its views on the most intimate feelings and experiences for those of the applicant, and this without any medical competence. It thereby required the applicant not only to prove that this orientation existed and amounted to a disease necessitating hormone treatment and gender reassignment surgery, but also to show the 'genuine nature' of her transsexuality although (...) the essential nature and cause of transsexualism are uncertain. ${ }^{28}$

The European Court of Human Rights found this a violation of Article 8 ECHR.

The Court of Justice was asked to rule on the limits which human rights pose in asylum cases to the assessment of the credibility of a declared sexual orientation. ${ }^{29}$ One of the applicants had argued that sexual orientation concerns one of the most basic essentials of self-determination, and that asylum authorities cannot substitute their views on the most intimate feelings and experiences for those of an applicant. The Court rejected this, saying that 'although it is for the applicant for asylum to identify his sexual orientation, which is an aspect of his personal identity' these statements can be the subject of a credibility assessment just like in cases not concerning sexual orientation. ${ }^{30}$ Thereby, the Court side-stepped the evident tension between the credibility assessment of sexual orientation in asylum cases and the Van Kück judgment. The Advocate-General in this case went further in acknowledging the tension. She starts out with the observation that individuals have a right to define their own identity which includes defining their own sexual orientation. (...) An applicant's definition of his own sexual orientation must therefore play an

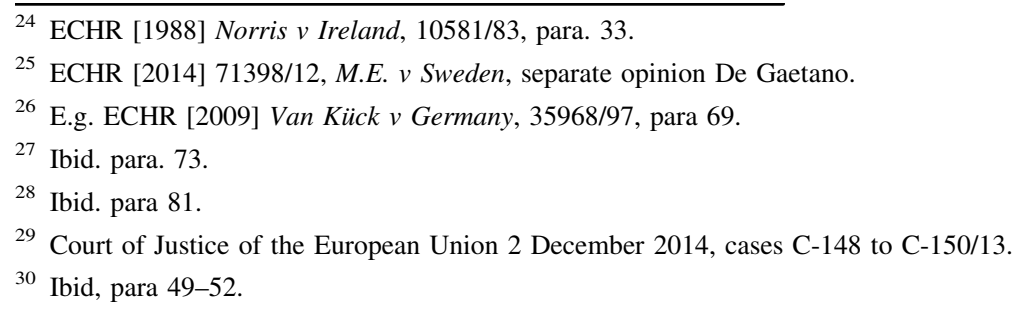


important role within the assessment process of applications for refugee status'. But then, the Advocate-General argues that like any other asylum claim, the claims of sexual minorities must be assessed by states in order to establish who is in genuine need of protection as a refugee, and this includes credibility assessment. So whereas the Advocate-General ends up at the same conclusion as the Court, she acknowledges the tension more clearly than the Court does.

The instability of the opposition between Europe as the location where human rights are realized and other parts of the world where this is not the case allows asylum seekers to claim inclusion instead of exclusion; and it is the same instability which allows states to exclude instead of include. This is why asylum is so elusive for both refugees and states: because of the instability, states cannot entirely control the outcome of asylum cases, but neither can asylum seekers compel asylum authorities or courts to decide to their benefit. The notion of Europe as characterized by human rights can be reiterated in such a manner that it legitimizes the exclusion of non-European asylum seekers, but this often implies the idea that human rights are not fundamental. Asylum seekers can seize the opportunity which this dissonance creates. They argue for their inclusion, because removing them to their country of origin would imply a European state facilitating the violation of their fundamental rights. Because of the simultaneous including and excluding potential of human rights law in this context, neither states nor asylum seekers can control the outcome of individual cases.

\section{Opportunities and Limitations}

Until World War II, European domination and exclusion were justified in terms that were unequivocally racial. Building on the work of Ann Laura Stoler, Sarah van Walsum has shown how, in the context of the regulation of family migration, lines of distinction are arranged and rearranged to produce a discourse of exclusion suited to the normative context at hand (Stoler 1995; Van Walsum 2008, p. 259). She analyses how after the war, the pre-war colonial system was replaced by one in which the relevance of race is denied. Family norms of mainstream society are perceived as modern, emancipated and egalitarian, while those of especially Muslim migrants are seen as still caught up in patriarchal traditions. Migration control is less about controlling the number of immigrants, and at face value it is not about the ethnic or racial background of people. Instead, it is about facilitating the admission of those who are expected to fit into the new normative order, and excluding those who are perceived to be a threat to the new order. In this way, the emancipatory project concerning family relations is closely related to defining who is to be excluded. Real or assumed differences in sexual behaviour and gendered family norms serve to distinguish citizens from non-citizens or good from bad citizens (Van Walsum 2008, pp. 268-276).

In addition to the family norms that Van Walsum has identified as an axis of inclusion and exclusion in Europe, the analysis presented here shows human rights to be another crucial concept in that respect. But like the earlier racial dividing lines, the new ones are unstable. Just as the European/non-European dichotomy itself is a 
construction, its destabilization is something that is worked on and which is fought for. The destabilization can be used to exclude as well as to include. Inclusion occurs as a result of the concerted efforts of asylum seekers and refugees, advocates, courts, academics, and others.

This observation is not entirely unproblematic. I want to stipulate (and then leave for another occasion) two questions. First, the instabilities are used for contestation-but why does contestation of European domination and exclusion occur in the context of asylum and refugee law, rather than in, say, feminism or trade unionism? Or is this just my refugee law myopia? To the extent that the contestation is indeed more pronounced in the context of migration and asylum, this may be related to these issues raising fundamental questions of cultural and national inclusion and exclusion. This is clearly more of an open nerve in contemporary Europe than political contestations that do not question the nation-state. Second, in refugee law, as we have seen, the instabilities are quite explicit and to some extent recognized by high profile institutional actors like the European Courts in the fields of religion and sexual orientation, while the instabilities go largely unnoticed in the context of gender (cases on forced marriage, FGM, single women). What can help us to understand the contrast between especially LGBT asylum cases, where the tension between human rights norms for internal use and for universal application is very much at the surface, and cases like those of the women from Yemen which are pretty much routine? Is it just the fear of the floodgates opening (there are more women in the world than LGBT people)? It might also be that LGBT rights are more highly valued in Europe than women's rights. LGBT rights may be less subversive (and therefore less threatening) than women's rights. Yet another possibility to be thought through is that the LGBT movement has been more successfully domesticated than the women's movement, or that it has been more successful politically (for example because it has been dominated by men). Both issues-why sexual and homonationalism are more of an issue in the context of asylum and migration than in other fields; and why has it been easier to make 'playing the game' problematic in LGBT cases than in women's cases - deserve further analysis.

But, to be sure, these instabilities are man-made. As Van Walsum has shown, it may happen that people with little power like migrant women are able to exploit them to their advantage. Van Walsum analysed how single migrant women have succeeded in reaping benefits from family to related case law which was developed in cases concerning European middle-class claimants (Van Walsum 2009). Over the past decade, LGBT asylum seekers have likewise seized on these instabilities so as to pressure asylum authorities to grant refugee status to persecuted lesbians, gays, bisexuals and transgenders. The issue has been acknowledged in European legislation (Article 10(1)(d) of Directive 2011/95 considers 'a group based on a common characteristic of sexual orientation' as a potential persecution ground). Twenty-five years of campaigning has resulted in asylum for women fleeing genderbased violence, but this now seems to have eroded to such an extent that many women are returned to their country of origin because they are expected to comply with even violent forms of patriarchy. It may be significant that, unlike sexual orientation, gender as such is not considered to be a persecution ground in European 
law, but only 'shall be given due consideration for determining' a persecution ground (Article 10(1)(d) Regulation 2011/95).

The dichotomy between Europeans and non-Europeans is continually being constructed and reconstructed. Potential instabilities can be brought to light or, alternatively, hidden. For both sides, defeats as well as successes are never stable and durable. It would not surprise me if the discourse on human rights in Europe and elsewhere were made to shift. With nationalist identity movements on the rise, one can well imagine (consonant with the European Court of Human Rights' wording in Z. and T. $v$ United Kingdom) a reformulation which marks human rights as cultural: European, or Western, or Judeo-Christian, or even national-as in the British critique of Strasbourg case law (inter alia Hoffmann 2009; Pinto-Duschinsky 2011) —rather than universal. This would reduce the tension on which asylum seekers seek to rely by downplaying the universalist pretensions of human rights, and would require renewed inventiveness on the side of those who do not want to define Europe through domination and exclusion.

Acknowledgements I am grateful for the feedback to earlier versions of this paper by Marcelle Reneman, Gregor Noll, Jan-Willem Duyvendak, and two anonymous reviewers; as well as during the Nordic Asylum Law Seminar in Uppsala, 8 May 2015; the NOISE Summer School, Utrecht University, 28 August 2015; the 'Between autonomy and vulnerability: Perspectives on migration' Colloquium, University of Neuchâtel, 20 May 2016; the LGBTIQ \& Asylum Seminar at the Vrije Universiteit Amsterdam, 25 November 2016; and the Critical Theory in the Humanities: Resonances of the Work of Judith Butler Conference at the Vrije Universiteit Amsterdam, 7 April 2017.

Open Access This article is distributed under the terms of the Creative Commons Attribution 4.0 International License (http://creativecommons.org/licenses/by/4.0/), which permits unrestricted use, distribution, and reproduction in any medium, provided you give appropriate credit to the original author(s) and the source, provide a link to the Creative Commons license, and indicate if changes were made.

\section{References}

Anker, Deborah E. 2002. Refugee law, gender, and the human rights paradigm. Harvard Human Rights Journal 15: 133-154.

Ayoub, Philip M., and David Paternotte. 2014. Introduction. In LGBT activism and the making of Europe. A rainbow Europe?, ed. Philip M. Ayoub and David Paternotte. Basingstoke/New York: Palgrave Macmillan.

Bilge, Sirma. 2012. Mapping Québécois sexual nationalism in times of 'crisis of reasonable accommodations'. Journal of Intercultural Studies 33: 303-318.

Butler, Judith. 2008. Sexual politics, torture, and secular time. British Journal of Sociology 59: 1-23.

Colpani, Gianmaria, and Adriano José Habed. 2014. 'In Europe it's different': Homonationalism and peripheral desires for Europe. In LGBT activism and the making of Europe. A rainbow Europe?, ed. Philip M. Ayoub and David Paternotte. Basingstoke/NewYork: Palgrave Macmillan.

Crawley, Heaven. 1997. Women as asylum seekers: A legal handbook. London: Refugee Action, Refugee Women's Legal Group and Immigration Law Practitioners' Association.

Goodwin-Gill, Guy S., and Jane McAdam. 2007. The refugee in international law. 3rd ed. Oxford: Oxford University Press.

Grahl-Madsen, Atle. 1966. The status of refugees in international law, vol. I. Leyden: Sijthoff.

Hall, Stuart. 1988. New ethnicities. In ICA-Documents 7, Black Film British Cinema, ed. Kobena Mercer. London: ICA Conference. 
Hathaway, James C., and Jason Pobjoy. 2012. Queer cases make bad law. New York University Journal of International Law and Politics 44: 315-390.

Hathaway, James C., and Michelle Foster. 2014. The law of refugee status. 2nd ed. Cambridge: Cambridge University Press.

Heijer, Den, Jorrit Rijpma Maarten, and Thomas Spijkerboer. 2016. Coercion, prohibition and great expectations. The continuing failure of the Common European Asylum System. Common Market Law Review 53: 607-642.

Hemme, Battjes. 2013. Accommodation: Sur place claims and the accommodation requirement in Dutch asylum policy. In Fleeing homophobia. Sexual orientation, gender identity and asylum, ed. Thomas Spijkerboer. Milton Park/New York: Routledge.

Hoffmann, Lord. 2009. The universality of human rights, Judicial Studies Board Annual Lecture, 19 March 2009. https://www.judiciary.gov.uk/announcements/speech-by-lord-hoffmann-theuniversality-of-human-rights/. Accessed on 19 Oct 2017.

Honig, Bonnie. 2001. Democracy and the foreigner. Princeton, New Jersey/Oxford: Princeton University Press.

Jansen, Sabine, and Thomas Spijkerboer. 2011. Fleeing homophobia. Asylum claims related to sexual orientation and gender identity in Europe. Amsterdam: COC Nederland/Vrije Universiteit.

Lage, Merle-Marei. 2016. Women fleeing gender-based violence and the European Court of Human Rights, master's thesis. Amsterdam: Vrije Universiteit.

Macklin, Audrey. 1995. Refugee women and the imperative of categories. Human Rights Quarterly 17: 213-277.

Millbank, Jenni. 2009. From discretion to disbelief: Recent trends in refugee determinations on the basis of sexual orientation in Australia and the United Kingdom. International Journal of Human Rights 13: 391-414.

Moss, Kevin. 2014. Split Europe: Homonationalism and homophobia in Croatia. In LGBT activism and the making of Europe. A rainbow Europe?, ed. Philip M. Ayoub and David Paternotte. Basingstoke/ New York: Palgrave Macmillan.

Pinto-Duschinsky, Michael. 2011. Bringing rights back home. Making human rights compatible with parliamentary democracy in the UK, London: Policy Exchange, https://www.policyexchange.org. uk/wp-content/uploads/2016/09/bringing-rights-back-home-feb-11.pdf. Accessed on 30 Oct 2017.

Puar, Jasbir K. 2007. Terrorist assemblages. Homonationalism in queer times. Durham/London: Duke University Press.

Said, Edward. 1991 [1978]. Orientalism. Western conceptions of the orient. London: Penguin Books.

Said, Edward. 1993. Culture and imperialism. New York: Alfred A. Knopf.

Spijkerboer, Thomas. 2000. Gender and refugee status. Aldershot: Ashgate.

Sreman, Srdjan, and R. Ruard Ganzevoort (eds.). 2015. Religious and sexual nationalisms in central and eastern Europe. Leiden: Brill.

Thomas, Spijkerboer, ed. 2013. Sexual identity, normativity and asylum. In Fleeing homophobia. Sexual orientation, gender identity and asylum, 217-238. London, New York: Routledge.

Stoler, Ann Laura. 1995. Race and the education of desire. Foucault's history of sexuality and the colonial order of things. Durham/London: Duke University Press.

Thym, Daniel. 2016. The 'refugee crisis' as a challenge of legal design and institutional legitimacy. Common Market Law Review 53: 1545-1573.

van Walsum, Sarah. 2008. The family and the nation. Dutch family migration policies in the context of changing family norms. Newcastle upon Tyne: Cambridge Scholars Publishing.

van Walsum, Sarah. 2009. Against all odds: How single and divorced migrant mothers were eventually able to claim their right to respect for family life. European Journal of Migration and Law 11: 295-311.

Wekker, Gloria. 2016. White innocence: Paradoxes of colonialism and race. Durham/London: Duke University Press.

Wessels, Janna. 2013. Discretion in sexuality-based asylum cases. An adaptive phenomenon. In Fleeing homophobia. Sexual orientation, gender identity and asylum, ed. Thomas Spijkerboer. London/New York: Routledge.

Wessels, Janna. 2016. 'Discretion', persecution and the act/identity dichotomy. Reducing the scope of refugee protection. Amsterdam: Vrije Universitei.

Yuval-Davis, Nira. 1997. Gender and nation. London/California/Delhi: Sage Publishers. 


\section{Legal Sources}

A.A. and others $v$ Sweden [2012] 14499/09. European Court of Human Rights 28 June 2012.

Ameh and others $v$ United Kingdom [2011] European Court of Human Rights 30 August 2011 (admissibility decision), 4539/11.

Bader and Kanbor v Sweden [2005] European Court of Human Rights 8 November 2005, 13284/04, para. 43-49.

Collins and Akaziebie v Sweden [2007] European Court of Human Rights 8 March 2007 (admissibility decision), 23944/05 (FGM, Nigeria).

D. et autres c. Turquie [2006] European Court of Human Rights 22 June 2006, 24245/03, para. 55-58.

Dudgeon v United Kingdom [1981] European Court of Human Rights 22 October 1981, 7525/76, para. 41.

F. v United Kingdom [2004] European Court of Human Rights (admissibility decision) 22 June 2004, 17341/03;

HJ (Iran) and HT (Cameroon) v State Secretary for the Home Department, [2010] UKSC 31, para. 22 and 61.

I.I.N. $v$ the Netherlands [2004] European Court of Human Rights (admissibility decision) 9 December 2004, 2035/04.

Izevbekhai and others v Ireland [2011] European Court of Human Rights 17 May 2011 (admissibility decision), 43408/08 (FGM, Nigeria).

M.E. v Sweden [2014] European Court of Human Rights 26 June 2014, 71398/12.

N. $v$ Sweden [2010] European Court of Human Rights 20 July 2010, 23505/09.

Norris v Ireland [1988] European Court of Human Rights 26 October 1988, 10581/83, para. 38.

Omoredo v Austria [2011] European Court of Human Rights 20 September 2011 (admissibility decision), $8969 / 10$.

Othman v United kingdom [2012] European Court of Human Rights, 17 January 2012, 8139/09.

R.H. v Sweden [2015] European Court of Human Rights 10 September 2015, 4601/14.

R.W. and others $v$ Sweden [2012] European Court of Human Rights 12 April 2012 (admissibility decision), 35745/11.

S.B. v Finland [2014] European Court of Human Rights 24 June 2014 (admissibility decision), 17200/11. Soering v Germany [1989] European Court of Human Rights 7 July 1989, 14038/88, para 100; Sow v Belgium [2016] European Court of Human Rights 19 January 2016, 27081/13.

Sufi and Elmi v United Kingdom [2011] European Court of Human Rights 28 June 2011, 8319/07 and 11449/07, para 275.

Van Kück v Germany [2009] European Court of Human Rights 12 September 2009, 35968/97, para 69.

Z. and T. v United Kingdom [2006] European Court of Human Rights 28 February 2006 (admissibility decision), 27034/05. 